\title{
Coğrafi Bilgi Sistemleri (CBS) Kullanılarak Bucak Havzası Yeraltısuyu Sertlik Haritasının Hazırlanması ve Kayaç-Su Etkileşiminin Yorumlanması
}

\author{
İ. İskender Soyaslan ${ }^{1 *}$, Kerem Hepdeniz ${ }^{2}$ \\ ${ }^{1}$ Burdur Mehmet Akif Ersoy Üniversitesi, Mühendislik Mimarlık Fakültesi, İnşaat Mühendisliği Bölümü, Burdur, Türkiye (ORCID: 0000-0001-5282-8094) \\ ${ }^{2}$ Burdur Mehmet Akif Ersoy Üniversitesi, Bucak E.G. Tek. Bil. MYO, Mimarlık ve Şehir Planlama Bölümü, Burdur, Türkiye (ORCID: 0000-0003-4182-5570)
}

(İlk Geliş Tarihi 4 Ocak 2020 ve Kabul Tarihi 22 Şubat 2020)

(DOI: $10.31590 /$ ejosat.670303)

ATIF/REFERENCE: Soyalsan, İ., İ., \& Hepdeniz, K., (2020). Coğrafi Bilgi Sisteleri (CBS) Kullanılarak Bucak Havzası Yeraltısuyu Sertlik Haritasının Hazırlanması ve Kayaç-Su Etkileşiminin Yorumlanması. Avrupa Bilim ve Teknoloji Dergisi, (18), 99-108.

$\ddot{O} \mathbf{z}$

Batı Akdeniz Bölgesi’nde Burdur İli güneyinde bulunan Bucak Havzası, ülkemizin en önemli karstik alanlarından biri olan Toros Karst Kuşağı üzerine konumlanmıştır. Farklı tektonik birliklerin bir araya gelmesinden oluşan Toros Karst Kuşağı, Batı Toros ve Orta Toros Karst alanı olmak üzere iki farklı bölgeye ayrılmaktadır. Bucak Havzası, iç ve yüzeysel karstlaşmanın iyi geliştiği Batı Toros Karst alanı içinde yer almaktadır. Havzanın kuzey, batı ve orta bölümünde allokton Akdağ Kireçtaşı ve güneyinde ise otokton Davraz Kireçtaşı bulunur. Bu iki birim kırıklı-çatlaklı ve erime boşluklu yapılarından dolayı karstik akiferi özelliği taşımaktadır. Aynı zamanda Bucak Havzasının komşu Antalya Havzası ile olan hidrodinamik bağlantısı, beslenme alanı içinden ve genellikle alüvyon tabanında bulunan bu akifer ile sağlanmaktadır. Türkiye'nin güneybatısında Burdur-Antalya karayolunun içerisinden geçtiği havzada Bucak ve Çeltikçi yerleşim alanları ve çok sayıda köy bulunmaktadır. Bucak ilçesi içme suyu ihtiyacı, havza içerisindeki iki kaynak ile ovada açılmış sondaj kuyuları aracılığıyla yeraltısuyundan karşılanmaktadır. Bucak havzası içerisinde yer alan 20 adet kuyudan 2011-2012 yıllarında alınan yeraltısuyu örneklerinde $\mathrm{CaCO}_{3}$ ve Fransız su sertlik değerleri tespit edilmiştir. Sertlik değerleri Coğrafi Bilgi Sistemleri ortamına işlenmiş, Kriging interpolasyon yöntemi kullanılarak analiz edilmiş ve tematik haritalar hazırlanmıştır. Ulusal ve uluslararası sınır değerleri kullanılarak sertlik değerleri karşılaştırılmış ve havzadaki yeraltısularının sert-çok, sert su sınıfında yer aldığı görülmüştür. Analizi gerçekleştirilen $\mathrm{CaCO}_{3}$ ve Fransız su sertlik değerlerine göre; çalışma alanının batısından doğusuna doğru sertlik değerleri artmaktadır. Özellikle havzanın doğusunda yer alan Davraz Kireçtaşlarının bulunduğu alanlarda belirgin sertlik anomalileri tespit edilmiştir. Yüksek sertlik değerlerinin sebebinin karstik Davraz Kireçtaşı akiferini oluşturan formasyonlar ile yeraltısuları arasındaki kayaç-su etkileşimi olduğu sonucuna varılmıştır.

\section{Using a Geographic Information System (GIS) to Mapping Groundwater Hardness in Bucak Basin and Interpretation of Rock- Water Interaction}

\begin{abstract}
Bucak Basin, located in the south of Burdur in the Western Mediterranean Region, is located on the Taurus Karst Belt, one of the most important karstic areas of our country. The Taurus Karst Belt, which is composed of different tectonic units, is divided into two different
\end{abstract}

\footnotetext{
* Sorumlu Yazar: Burdur Mehmet Akif Ersoy Üniversitesi, Mühendislik Mimarlık Fakültesi, İnşaat Mühendisliği Bölümü, Burdur, Türkiye, ORCID: 0000-0001-5282-8094, isoyaslan@gmail.com
} 
regions as West Taurus and Middle Taurus Karst areas. The Bucak Basin is located within the Western Taurus Karst area, where internal and superficial karstification develops well. In the north, west and middle part of the basin, there is an allochthonous Akdağ limestone and in the south, the autochthonous Davraz limestone. These two units have the characteristics of karstic aquifer due to their fracturecracked and melt-capped structures. At the same time, the hydrodynamic connection of the Bucak Basin to the neighboring Antalya Basin is provided by this aquifer, which is generally located at the alluvial floor through the feeding area. Burdur-Antalya in southwest Turkey late in the basin Çeltikçi highway districts and residential areas and there are many villages. The drinking water requirement of the district of Bucak is met from the groundwater by means of two wells in the basin and drilling wells in the plain. $\mathrm{CaCO}_{3}$ and French water hardness values of groundwater samples taken from 20 wells in Bucak basin in 2011-2012 were determined. Hardness values were processed into Geographical Information Systems, analyzed using Kriging interpolation method and thematic maps were prepared. Hardness values were compared by using national and international limit values and it was found that groundwater in the basin was classified as hard-very hard water. According to $\mathrm{CaCO}_{3}$ and French water hardness values; hardness values increase from west to east of the study area. Significant hardness anomalies were detected especially at the points of Davraz limestones located to the east of the basin. It was concluded that the rock-water interaction between groundwater and the formations forming the karstic Davraz limestone aquifer is the reason for the high hardness values.

Keywords: Bucak Basin, Groundwater, Hardness, GIS, Rock-water interaction.

\section{Giriş}

CBS'ni çok farklı bilim dallarından farklı alanlardaki kullanıcılar tarafından farklı amaçlarla kullanılmasından dolayı, kabul gören tek bir tanımlaması bulunmamaktadır. En genel hali ile CBS, dünya üzerindeki konumsal olarak ifade edilebilen tüm bilgilerin toplanması, depolanması, karşılıklı sorgulanması ve görüntülenmesi işlemlerini sağlayan bilgisayar yazılım destekli bir araçtır. Ayrıca CBS, koordinatlandırılarak konumsal referanslı olarak ifade edilebilen farklı yöntemler kullanılarak verilerin analizi, sorgulanması ve elde edilen sonuçların tematik haritalar aracığıyla görüntülenmesini sağlayan bilgisayar destekli veri tabanı yönetim sistemidir (Yomralığlu, 2000).

Son yıllarda gelişen teknoloji sayesinde, giderek önemi artan harita tabanlı verilerin depolanması ve analizinin kolaylaşması, kullanıcılara büyük imkânlar sağlamıştır. CBS teknolojisi, haritalardaki mekânsal unsurlara ait bilgileri içeren öznitelik tabloları sayesinde sorgulamalar yapabilmektedir. Böylece çalışılan bölgelere ait oluşturulan tablolarla sorgulama yapmak yerine tematik haritalar üretilmeye başlanmıştır. CBS'nin tüm bu özellikleri sayesinde, kolayca yorumlanabilen tematik haritalar üzerinden ekonomik, hızlı ve doğru karar alınabilme imkânı sağlanmıştır (Dinç, 2000).

CBS, yeraltısuyunun kalite parametrelerinin değerlendirilmesinde en yangın kullanılan yöntemlerden bir tanesi olup yerli ve yabancı literatürde bu konuda çok sayıda çalışma bulunmaktadır (Kavurmacı ve ark., 2010; Öztürk ve Çelik, 2008; Çemek ve ark., 2005; George ve ark., 2015; Mantzafleri ve ark., 2009; Adnan ve Iqbal, 2014; Oroji, 2018; Mane ve ark., 2015; Jeihouni ve ark., 2014; İleri ve ark., 2007). Kullanılabilir nitelikteki tatlı su, dünyadaki tüm canlıların hayatta kalabilmeleri için gerekli olan en temel ihtiyaçtır. Canlılar bu ihtiyaçlarını yüzey ve yeraltısuyu kaynaklarından karşılamaktadırlar. Bu kaynaklar özellikle son yıllardaki artan nüfus ve endüstrileşmeye bağlı olarak; evsel, endüstriyel ve tarımsal kirlilik tehditleri altında kullanım koşulları giderek sınırlanmaktadır. Özellikle yüzey suları kirlilik risklerinden çok daha hızlı bir şekilde etkilenmekte ve kaliteleri geri dönülemez bir noktaya gelmektedir. Bundan dolayı günümüzde tatlı su kaynağı olarak yeraltısularının önemi giderek artmaktadır (George ve ark., 2015).

Özellikle son on yıl içerisinde kardiyovasküler ölüm nedenleri ile ilgili çevresel faktörler üzerine yapılan çalışmalar, içme suyu sertliğinin etkili bir faktör olduğunu göstermiştir (Sengupta ve ark., 2013). Özellikle epidemiolojik araştırmalar kalp damar hastalığı riski, büyüme geriliği, üreme yetersizliği, diyabet, sinir hastalıkları ve böbrek fonksiyonu bozuklukları ile su içerisinde çözünmüş kalsiyum $\left(\mathrm{Ca}^{++}\right.$ve magnezyum $\left(\mathrm{Mg}^{++}\right)$içeriğinin ilişkisini ortaya koymaktadır. Bunun yanında sert suların kullanımı sonucunda; aşırı sabun tüketimi, hassas ciltlerde kaşıntı, tahriş ve hatta ekzema görülmektedir (McNally ve ark., 1998). Sert suların kullanımı sonrası başta estetik sorunlar olmak üzere; sıcak su borularında ve ısıtıcı cihazlarda kireçlenme ve kabuklanma, giysilerde yıpranma, porselen ve cam mutfak eşyalarında kireç lekeleri ve çizilmeler görülebilmektedir (Nas ve Berktay, 2001; Şengül veKüçükgül, 1995).

\section{Materyal ve Metot}

\subsection{Materyal}

Bucak Havzası, Burdur ilinin güneyinde Burdur-Antalya karayolu güzergâhı üzerine yaklaşık $684,41 \mathrm{~km}^{2}$ 'lik bir alana sahiptir (Şekil 1). Genel olarak topoğrafya çok engebeli olup, sarp dağlar bölgeye hâkim, düzlük alanları ise ovaları oluşturmaktadır. Havzanın doğu ve batısı boyunca kuzeyden güneye doğru yüksek jeomorfolojik yapı hâkimken, güney ve orta kesimlerinde ise daha düşük kota sahip peneplen jeomorfoloji görülmektedir.

Güneybatı Anadolu'da Batı Toroslar'da bulunan Bucak Havzası, Isparta büklümü olarak bilinen tektonik bölgenin batı kesiminde yer almaktadır. Isparta büklümünün doğu kanadı Batı Toroslar’a, batı kanadı ise Likya Torosları olarak adlandırılır. Bükümün her iki kanadı kuzeydoğu ve kuzeybatı uzanımla Eğirdir-Hoyran Gölü kuzeyinde kesişmişlerdir. Bu tektonik kuşak Blumenthal (1951)'in “Coubure d' Isparta-Isparta Büklümü” olarak isimlendirdiği Isparta açısını meydana getirmiştir (Blumenthal, 1951; Bozcu, 1996). Bölgede otokton konumlu istifler; Beydağları otoktonunu ve Anamas-Akseki otoktonudur. Allokton konumlu istifleri ise, Antalya, Beyşehir-Hoyran ve Likya naplarından oluşur (Brunn ve ark., 1971). 


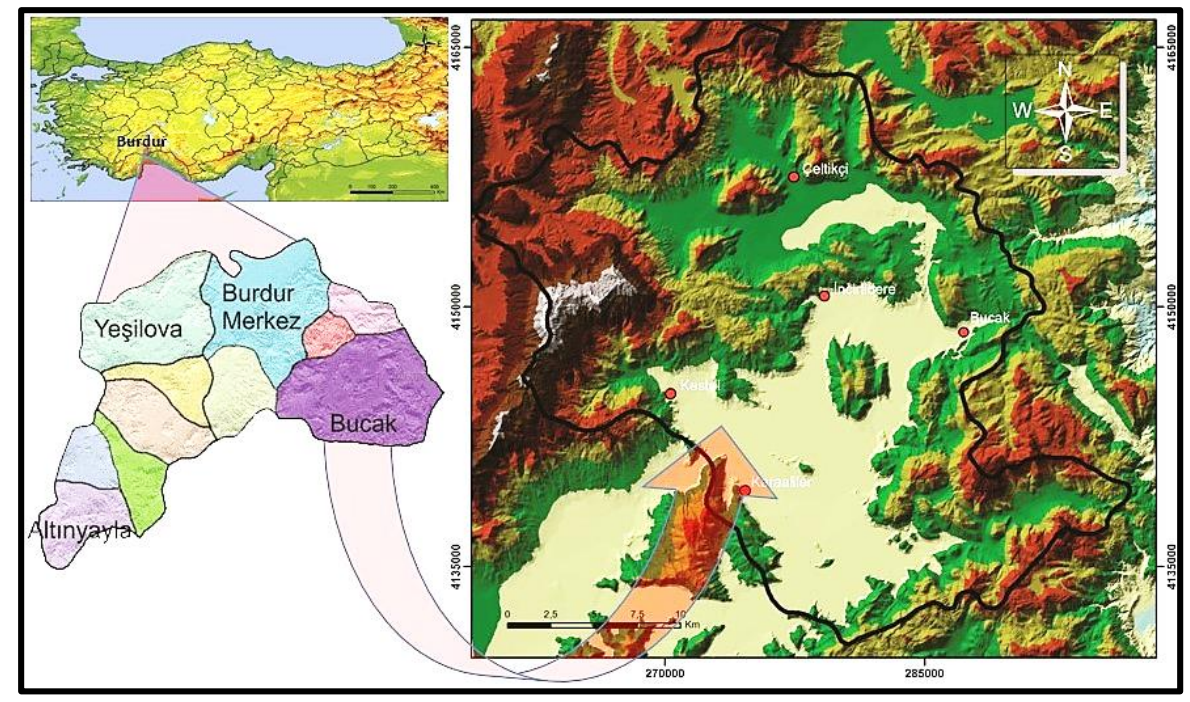

Şekil 1. Çalı̧̧ma alaninın yer buldur haritası

\subsubsection{Genel Jeoloji}

Çalışma alanında bulunan Mesozoik ve Senozoik'e ait kaya birimleri temelde otokton birimler ve allokton birimler olarak iki gurup altında toplanırlar. Otokton birimler yaşlıdan gence doğru sırayla Turoniyen-Alt Senoniyen yaşlı Davraz Kireçtaşı, Maestrihtiyen yaşlı Çiğdemtepe Formasyonu, Paleosen-Alt Eosen yaşlı Kızılkırma Formasyonu, Orta Eosen yaşlı Kayıköy Formasyonu, Burdigaliyen yaşlı Ağlasun Formasyonu, Orta-Üst Miyosen yaşlı Aksu Formasyonu, ile Kuvatener yaşlı Alüvyon olarak verilebilir. Allokton birimler ise Mesozoyik yaşı Akdağ Kireçtaşı ile Isparta ofiyolitik melanj olup, bölgeye yerleşim yapı olan Mesozoyik bölümünde tektonostratigrafik olarak incelenmiştir (Şekil 2).

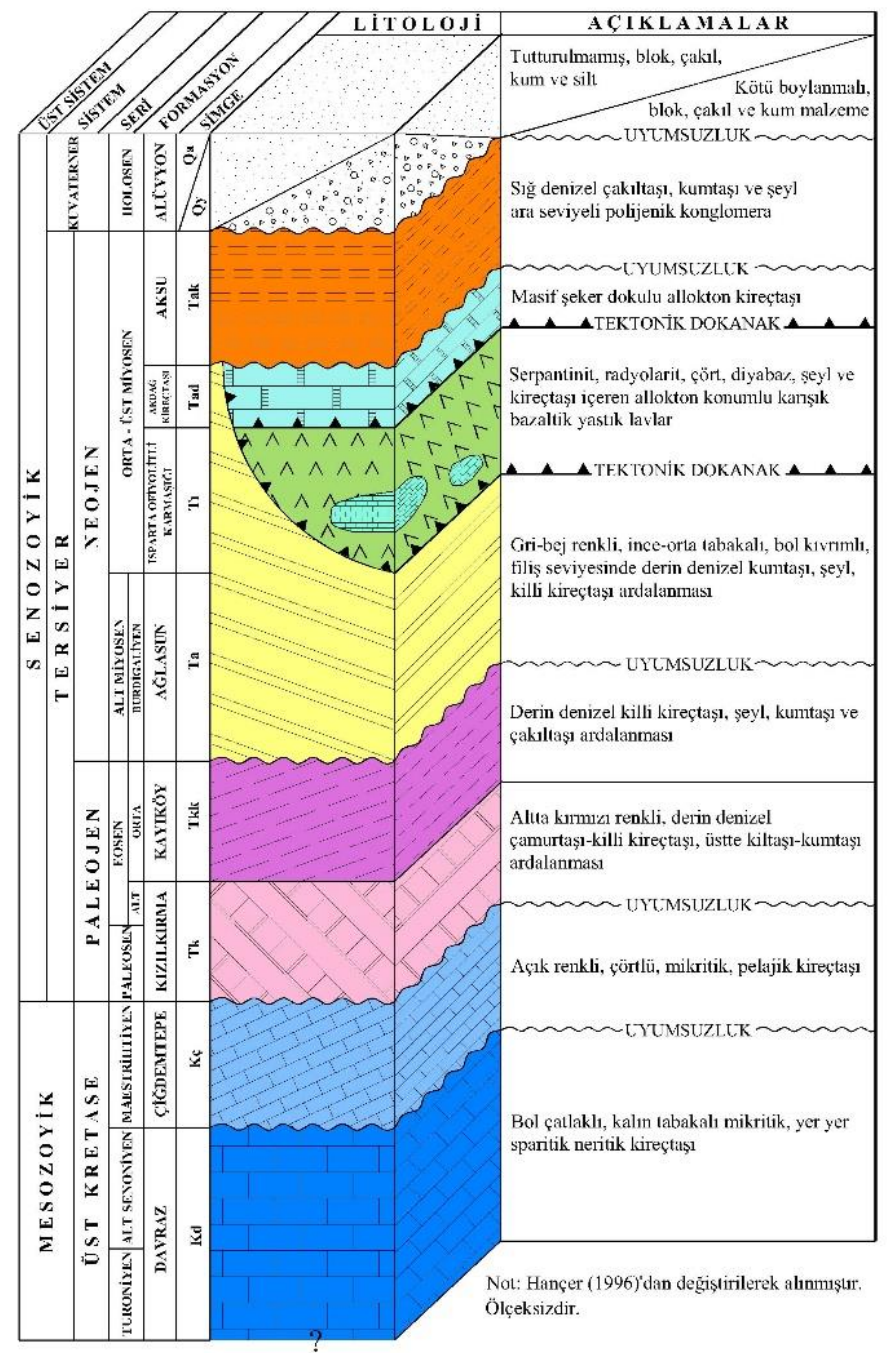

Şekil 2. Çalışma alanının genelleştirilmiş tektonostratigrafik sütun kesiti 
Kayaç su etkileşimi çerçevesinden yeraltısularına sertlik özelliği kazandıran en önemli litolojiler Davraz Kireçtaşı ve Akdağ Kireçtaşı'dır. Davraz Kireçtaşı, Batı Toroslar'daki Mesozoyik karbonat platformunun bir parçası olup platformun daha ziyade üst seviyelerini oluşturur. Birim aynı zamanda Beydağları otokton kuşağı olarak adlandırılmıştır (Ersoy, 1990).

Davraz Kireçtaşı, Güneybatı Türkiye'de Liyas'dan Alt Senoniyen'e kadar devam eden transgresyon (Koçyiğit, 1981) sırasında çökelen karbonatların üst kesimlerini oluşturan sığ denizel, neritik ortamı karakterize etmekte ve lagüner ortamı temsil etmektedir. Woodcock ve Robertson'un (1977) Beydağları zonu; Yılmaz ve ark., 'nın (1981) Beydağları masifi olarak belirttiği kuşağın Isparta güneyindeki devamı olan Davraz Kireçtaş1 otokton konumludur (Woodcook ve Robertson, 1977; Yılmaz ve ark., 1981).

Davraz Kireçtaşı; gri, beyaz ve krem renkli sert ve bol çatlaklı olup çatlaklar ikincil kalsit dolgulu, $10 \mathrm{~cm}$ ile $1 \mathrm{~m}$ arasında kalınlıkta, orta-kalın tabakalı litolojiye sahiptir. Neotektonik dönemde etkili olan tektonizma sonucunda birimde, kırıklı ve ezilmiş breşik zonlar dikkati çekmektedir. Çalışma alanında birime ait karstik erime yapılarından polyeler özellikle de morfolojik olarak üst kotlarda, uvalalar özellikle Kuyubaşı civarında, daha küçük boyutlu lapiyeler ise birimin yüzeylendiği tüm noktalarda sıklıkla gözlenmektedir. Davraz kireçtaşlarında karstik yapılardan özellikle düdenler hâkim olarak gözlenmektedir. Bölgede bulunan Kestel Gölü'nün kurutulması sırasında da ova kenarında yer alan çok sayıda düdenlerden faydalanılmıştır. Onaç Barajından bırakılan sulardan beslenen Onaç Dereside Kestel Düdenine boşalmaktadır (Şekil 3). Bucak ilçesi kanalizasyonu arıtma tesisi yapılmadan önce Onaç Deresi aracılığıyla Kestel Düdenine bırakılmıştır. Karstik bir morfolojinin gelişmesi için tüm şartlara sahip olan Davraz Kireçtaşı karstik litolojilerin tüm karakteristik özelliklerini taşımaktadırlar. Davraz Kireçtaşı’nın tabanı inceleme alanında görülemediğinden dolayı en yaşlı birim olarak en altta bulunmaktadır. Birimin üzerinde ise uyumsuz olarak Çiğdemtepe Formasyonu yer almaktadır (Hançer, 1996).

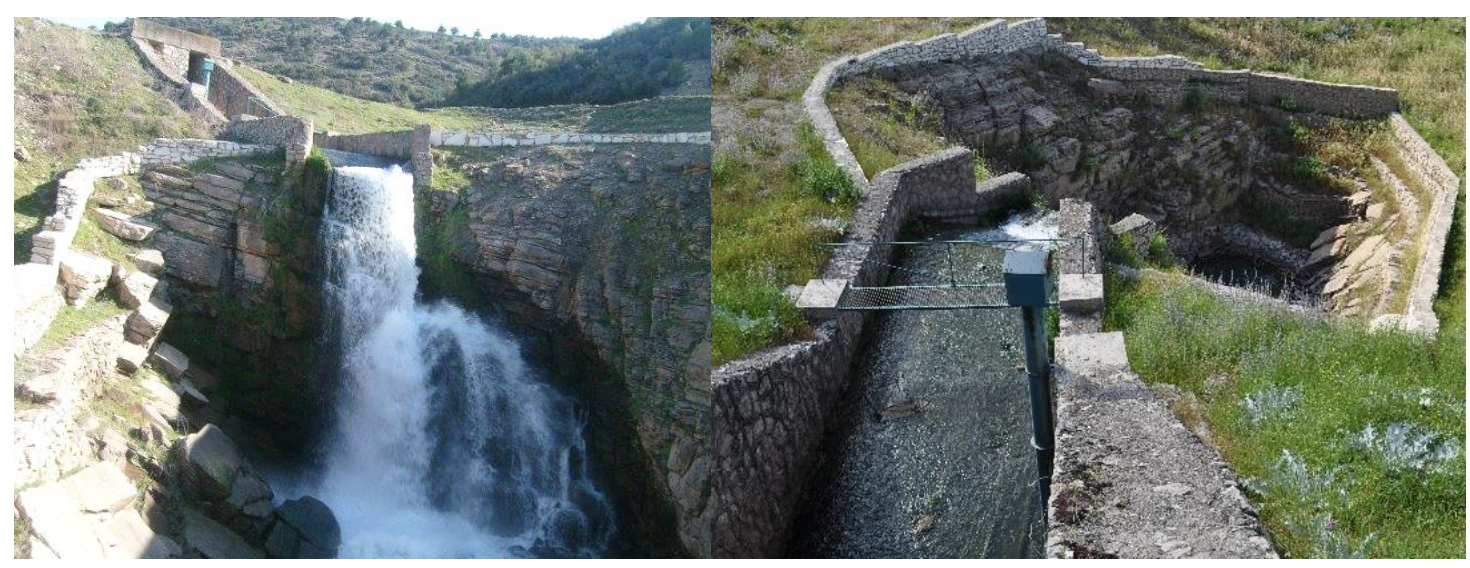

Şekil 3. Onaç deresinin boşaldı̆̆ı Kestel Polyesi

Allokton konumlu Akdağ Kireçtaşı birimi Isparta ofiyolitik melanjı ile birlikte tektonik kökenli kuvvetlerce Burdigaliyen'de Ağlasun Formasyonu üzerinde uyumsuz olarak konumlanmıştır. Birim beyaz, açık gri renkli, 1-25 cm arasında değişen boyutlarda bol çatlaklı, kalsit dolgulu masif kireçtaşından oluşmaktadır. Tabakalı bir yapı göstermeyen birimde çok düzgün çatlak düzlemleri gelişmiş olup, arazi çalışmalarında uzaktan tabakayı andırmaktadır. Davraz Kireçtaşı'nda görünen karstik erime yapılarının tamamı Akdağ Kireçtaşı'nda yaygın olarak gözlenmektedir. Birim Isparta ofiyolitik melanji ile birlikte allokton konumlu olarak Ağlasun Formasyonu üzerine bindirmeli dokanakla gelmişlerdir. Birimin alt dokanağında tektonostratigrafik olarak Isparta ofiyolitik melanjı, üstünde ise uyumsuz olarak Aksu Formasyonu bulunmaktadır (Hançer, 1996).

Bucak Havzasının doğu ve güney kesiminde geniş alanlarda Beydağları otoktonuna Davraz Kireçtaşı, batısında ise allokton konumlu Akdağ Kireçtaşı yüzeylenmektedir (Şekil 4). Ova genelinde allokton konumlu Akdağ Kireçtaşı ile Isparta ofiyolitik melanj dokanağından boşalan kaynaklar ve yağıştan beslenen alüvyon akifer boşalımının otokton konumlu karstik Davraz Kireçtaşı'na olmaktadır (Karagüzel ve ark., 1995). 


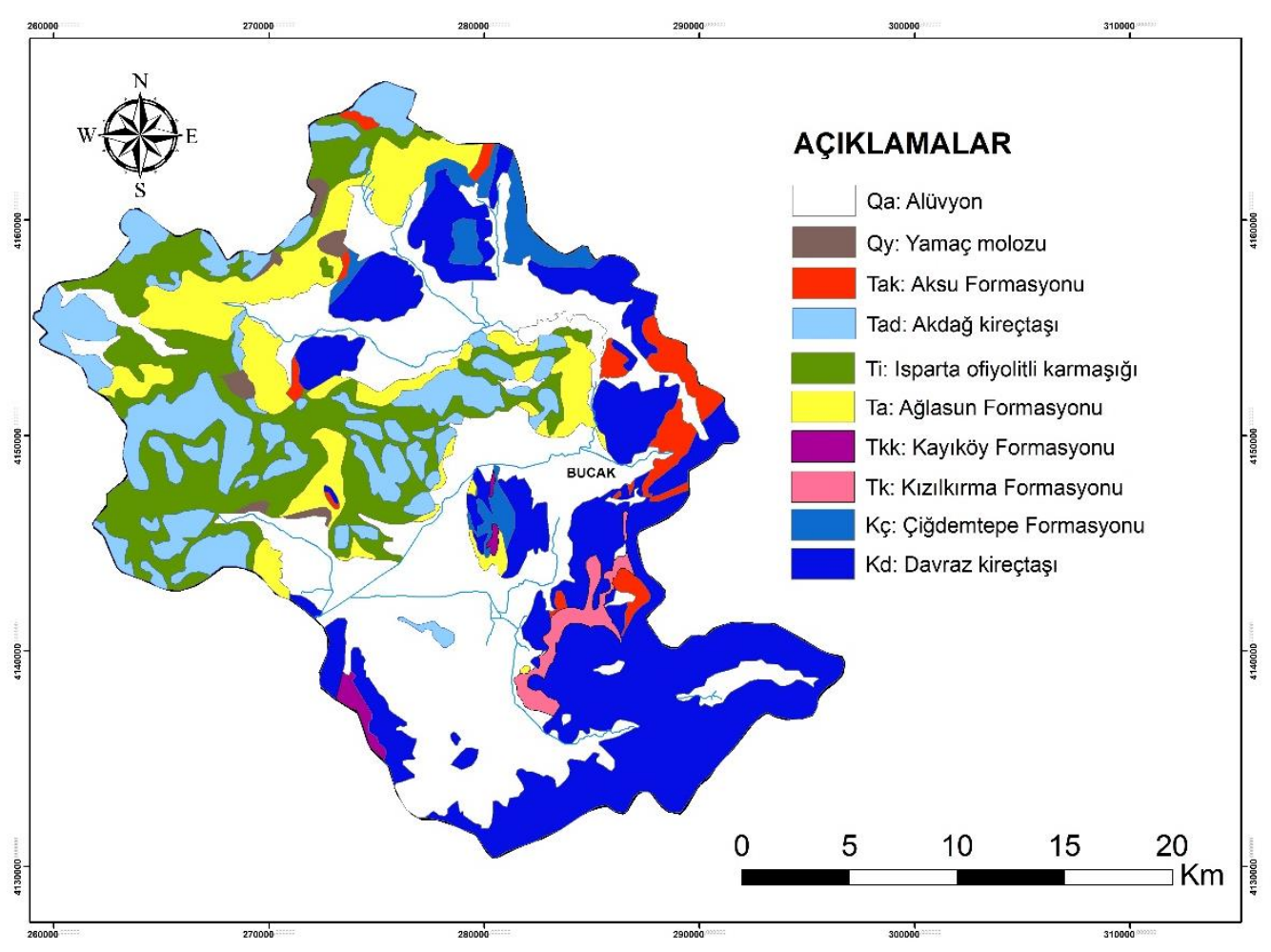

Şekil 4. Çalışma alanının jeoloji haritası

\subsubsection{Su Sertliği}

İçme suyunda sertlik, suda çözünmüş doğal minerallerden $\mathrm{Ca}^{++}$ve $\mathrm{Mg}^{++}$konsantrasyonuna bağlı olarak oluşur ve litre başına çözünmüş kalsiyum karbonat $\left(\mathrm{CaCO}_{3}\right)(\mathrm{mg} / \mathrm{L})$ olarak ifade edilir. Bu mineraller toprak, kireçtaşı, kalsit, bazı volkanik bazaltlar gibi litolojiler ile yeraltısuyu arasında gerçekleşen etkileşim sonucunda doğal olarak çözülür (ES, 2019). Sudaki çözünmüş $\mathrm{Ca}^{++}$ve $\mathrm{Mg}^{++}$ oranı; hem suyun sertliğini belirleyen ve hem de suyun sağlık sorununa neden olduğunu gösteren çok önemli bir faktördür. Sertlik en yaygın kaynakları su içinde $\mathrm{Ca}^{++}$(kireçtaşı) ve $\mathrm{Mg}^{++}$(dolomit veya dolomitik kireçtaşı) olarak tanımlanmaktadır. Sertlik genellikle yeraltısuyu, $\mathrm{Ca}^{++}$ve $\mathrm{Mg}^{++}$içeren mineraller içinden süzülürken kayaç-su etkileşimi sonucunda oluşmaktadır (Prepas, ve diğerleri, 2001).

Hangi kaynaktan geldiğine ve kayaç su etkileşiminin miktarına bağlı olmak üzere yeraltısularının sertlikleri genellikle yüzey sularının sertliklerinden daha fazladır. Genellikle sedimanter kayaçlardan özellikle kireçtaşı veya dolomitik kireçtaşları ile uzun süre etkileşimde bulunan suların sertlikleri, mağmatik kayaçlardan özellikle granitik kökenli kayaçlar ile etkileşimde bulunan suların sertliklerinden daha fazladır. Burada önemli olan jeolojik ortamın yani kayacın kökeni ve bileşimi ile suyun içerisindeki asidik karakterin miktarıdır.

Özellikle yağışların yeryüzü ile teması sonucunda yüzeysel akış ve yeraltına sızmasında karbondioksit ile etkileşime girerek karbonik asit meydana gelir. Karbonik asit ise kireçtaşı veya dolomitik kireçtaşını eriterek bikarbonat $\left(\mathrm{HCO}_{3}^{-}\right)$haline dönüştürür. $\mathrm{HCO}_{3}{ }^{-}$ 'ların su içinde erime yeteneği kalkerin erime yeteneğinden çok daha fazladır (Gölhan ve Aksoğan, 1968). Kireçtaşı ile etkileşim halinde bulunan yeraltısuyunun doğal olarak sertlik değeri artmaktadır.

Terminolojide sertlik ifade etmek için geçici sertlik, kalıcı sertlik, toplam sertlik ifadeleri kullanılmaktadır. Geçici Sertlik, $\mathrm{HCO}_{3}^{-}$‘

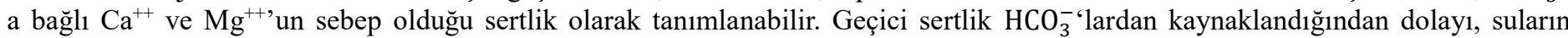
kaynatılması ile kolaylıkla giderilir. Kalıcı sertlik, $\mathrm{Ca}^{++}$ve $\mathrm{Mg}^{++}$gibi iyonların asit kökleri olan sülfat $\left(\mathrm{SO}_{4}^{-}\right)$, nitrat $\left(\mathrm{NO}_{3}^{-}\right)$ve klora $\left(\mathrm{Cl}^{-}\right)$ bağlı olarak meydana gelmekte olup, karbonat olmayan sertlik olarak ta tanımlanmaktadır. Geçici sertliğin aksine kalıcı sertlik suyun kaynatılması ile giderilememektedir. Toplam Sertlik ise geçici sertlik ve kalıcı sertliğin birleşimi olup, alkalinite ve karbonat olmayan sertliğin toplamıdır. Sudaki sertliği ifade etmek için, Fransız, Alman, İngiliz ve Amerikan sertlik dereceleri kullanılmaktadır.

İçme suyu serliği $\left(\mathrm{CaCO}_{3}\right)$ konusunda EPA(Environmental Protection Agency= Çevre Koruma Ajansı) ve Türk Standarlar Enstitüsü TS266 İçme Suyu Standardında tarafından belirlenmiş her hangi bir sınır değer ve sınıflama mevcut değildir (TSE, 1997; EPA, 2018; Güler, 1997. Bunun yanında WHO (World Heath Organization=Dünya Sağllk Örgütü) içme suyu standartlarında kabul edilebilir en üst sertlik $\left(\mathrm{CaCO}_{3}\right)$ sınır değeri $500 \mathrm{mg} / \mathrm{L}$ verilmiştir (WHO, 1996; Yelekçi ve ark., 2012). Suların sertlik derecesine göre sınıflamaları Tablo 1'de verilmiştir. 


\begin{tabular}{c|c}
\hline $\mathbf{C a C O}_{3}$ Miktarı (mg/L) & Su Sertlik Sınıfı \\
\hline $50-75$ & Yumuşak \\
\hline $75-150$ & Orta sert \\
\hline $150-300$ & Sert \\
\hline$>300$ & Çok sert \\
\hline Sertlik Değeri (ofH) & Su Sertlik Sınıf \\
\hline $0-7$ & Tatlı \\
\hline $7-14$ & Yumuşak \\
\hline $14-28$ & Orta sert \\
\hline$>28$ & Sert \\
\hline
\end{tabular}

Son zamanlarda yapılan su kalitesinin sağlığa etkisini konu alan çalışmalarda $\mathrm{Ca}^{++}$ve $\mathrm{M}^{++}$iyonlarından kaynaklanan sertliğin sağlıklı bireylerde dermotolojik hassasiyet hariç olumsuz ciddi bir etkiye sebep olmadığı anlaşılmıştır. Hatta suların sertliği ile kalpdamar hastalıklarının arasında ters bir ilişki bulunmaktadır (Anderson ve ark., 1975; Sengupta ve ark., 2013; Sengupta, 2012). Sert sular kullanım suyu olarak pek çok dezavantajlara sahipken, içme suyu olarak tüketildiğinde özellikle sağlık açısından önemli avantajlarının olduğunu söylemek mümkündür.

\subsection{Metot}

Araştırma kapsamında Mayıs-Eylül 2010 ve Mayıs-Eylül 2011 arasındaki dönemde arazi çalışmaları yapılmıştır. Ölçümler açık arazide yapıldığından, ölçüm zamanları hava şartlarına bağlı olarak belirlenmiştir. Aynı zamanda mümkün olduğunca aynı dönemlerde ölçümlerinin gerçekleştirilmesine çalışılmıştır. Çalışma alanındaki arazi ölçüm noktalarının seçimine dikkat edilerek, mümkün olduğunca araziyi temsil edebilecek noktaların seçilmesine özen gösterilmiştir. Arazi ölçümlerinin yapıldığı noktaların koordinatları, GPS (Küresel Konumlandırma Sistemi) cihazı ile 1-3 m aralığındaki hassaslık ile belirlenmiştir.

Yeraltı suyu sertlik değerlerinin belirlenmesi amacıyla Sanxin marka Portatif su sertlik ölçüm cihazı kullanılmıştır. Portatif su sertlik ölçüm cihazı $\mathrm{CaCO}^{3}$ su sertliğini $0-1000 \mathrm{mg} / \mathrm{L}$ ve Fransız su sertliğini $\left({ }^{\circ} \mathrm{fH}\right.$ ) $0-100{ }^{\circ} \mathrm{fH}$ aralıklarında $\pm \% 5$ hassasiyetinde ölçüm yapabilmektedir. Bu cihazla yeraltı suyu sertlik değerleri Fransız $\left({ }^{\circ} \mathrm{fH}\right)$ sertliği ve $\mathrm{CaCO}^{3}(\mathrm{mg} / \mathrm{L})$ sertliği olmak üzere yerinde ve gerçek zamanlı olarak ölçülmüştür.

Bilinen noktasal verilerden, bilinmeyen bölgelere ait verilerin elde edilmesinde kullanılan ArcGIS Mekansal analiz eklentisi sayesinde sürekli bir yüzey elde etmek ve çalışma alanına ait su sertliğini gösterir sürekli yüzey oluşturmak mümkün olmuştur (Singh \& Khan, 2011). Bu amaçla çalışmada, ArcGIS mekânsal analiz interpolasyon yöntemlerinden biri olan Kriging yöntemi kullanılmıştır. Kriging yöntemi ile interpolasyonda, ölçümü bulunmayan bölgelerdeki değerlerin tahmininde, ölçülen noktalara ait değerlerin genişletilerek tahmini yapılacak alan içine yayılması şekilde uygulanmaktadır. Kriging yönteminde şu eşitlik kullanılmaktadır.

$\mathrm{Z}_{\left(\mathrm{x}_{0}\right)}=\sum_{\mathrm{i}=0}^{\mathrm{n}} \lambda_{0}^{\mathrm{i}} \mathrm{Z}_{\left(\mathrm{x}_{\mathrm{i}}\right)}$

$\mathrm{Z}_{\left(\mathrm{x}_{0}\right)}: x_{0}$ noktası için hesaplanan değer,

$\lambda_{0}^{\mathrm{i}}:$ her i (i=1, 2, 3,....n) veri noktası ile ilişkili ağırlık,

$\mathrm{Z}_{\left(\mathrm{x}_{\mathrm{i}}\right)} \quad: x_{i}$ noktasındaki varolan değer,

n : örnek noktalarının sayısıdır.

Kriging yöntemi kullanılarak ve 20 adet kuyuya ait su örneklerinin Fransız ( $\left.{ }^{\circ} \mathrm{fH}\right)$ sertliği ve CaCO3 (mg/L) sertliğinin mekânsal dağılım haritası elde edilmiştir.

\section{Araştırma Sonuçları ve Tartışma}

Kriging yöntemi kullanılarak elde edilen $\mathrm{CaCO}^{3}$ sertliği mekânsal dağılım haritası incelendiğinde; en düşük sertlik değerinin 212 $\mathrm{mg} / \mathrm{L}$ ve en yüksek değerin ise $461 \mathrm{mg} / \mathrm{L}$ olduğu görülmüştür. En düşük sertlik değeri (212 mg/L) ova içerisindeki alüvyon akiferde, en yüksek sertlik değeri (461 mg/L) ise çalışma alanı doğusunda yer alan otokton konumlu çalışma alanının tabanını oluşturan Davraz kireçtaşlarının oluşturduğu karstik akifere yakın bölgede yer almaktadır (Şekil 5). 


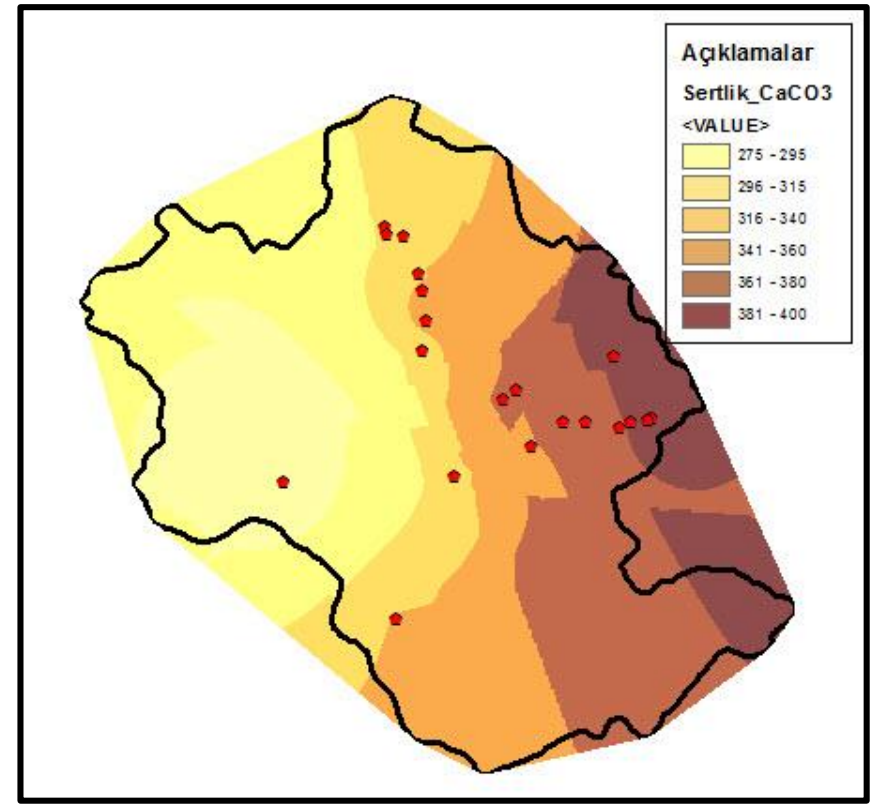

Şekil 5. Bucak havzası yeraltısuyu CaCO3 sertliği dă̆llım haritası

Fransız sertliği haritasında en düşük sertlik değeri $21^{\circ} \mathrm{fH}$ ve en yüksek sertlik değeri ise $46^{\circ} \mathrm{fH}$ olarak belirlenmiştir. En düşük sertlik değeri $\left(21^{\circ} \mathrm{fH}\right)$ ova içerisindeki alüvyon akiferde, en yüksek $\left(46^{\circ} \mathrm{fH}\right)$ sertlik değeri Davraz Kireçtaşlarının alüvyon akifere boşalım noktasına yakın bölgede bulunmaktadır (Şekil 6).

Bucak havzasında elde edilen her iki sertlik değerinin dağılımı doğudan batıya doğru artış göstermektedir. Çalışma alanı batısunda genellikle Isparta ofiyolik melanjı içindeki Akdağ kireçtaşları ile alüvyon dokanağında yer alan kaynaklar veya sondaj kuyularında sertlik değeri düşüktür. Bunun yanında çalışma alanı batısunda ise Davraz kireçtaşlarının kuzeyden güneya yayılım gösterdiği noktalarda sertlik değerlerinde bariz artış anomalisi gözlenmektedir.

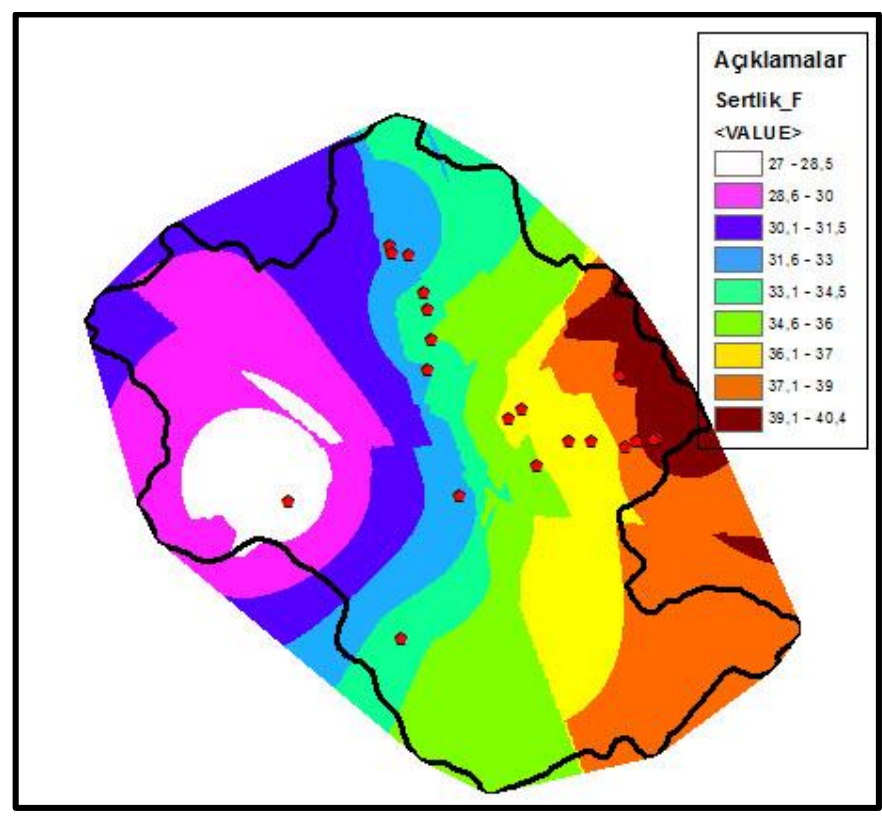

Şekil 6. Bucak havzası yeraltısuyu Fransız ('fH) sertlik dă̆glım haritası

Ölçülen $\mathrm{CaCO}^{3}$ sertlik değerlerine ait frekans dağılım grafiğinde en düşük değer $212.32 \mathrm{mg} / \mathrm{L}$, en yüksek değer $525.66 \mathrm{mg} / \mathrm{L}$, ortalama $350.08 \mathrm{mg} / \mathrm{L}$ ve standart sapma değerinin 74.90 olarak belirlenmiştir (Şekil 7). 


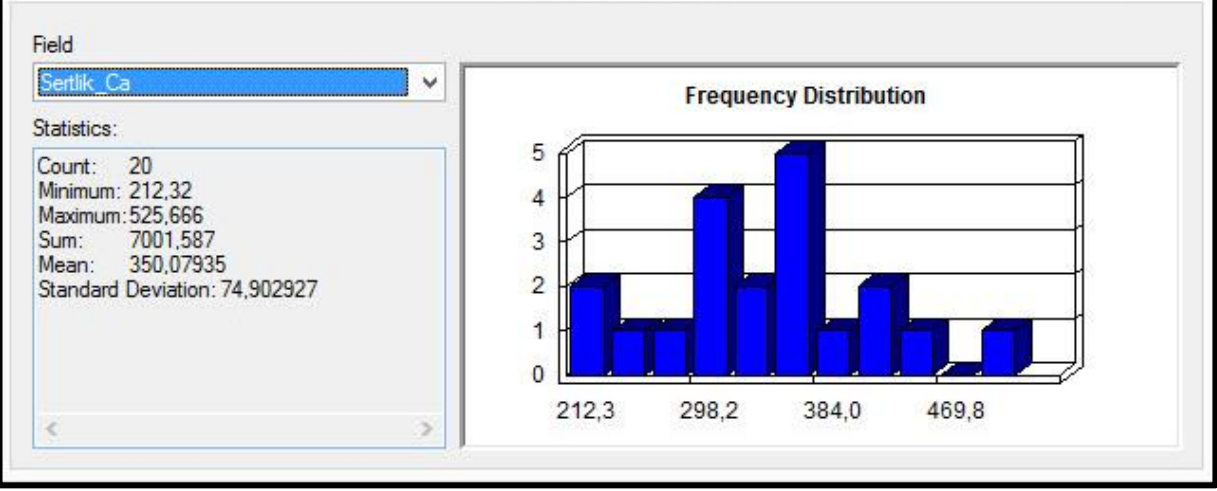

Şekil 7. CaCO3 sertliği için frekans dă̆ıllım

Ölçülen Fransız sertlik değerlerine ait frekans dağılım grafiğginde en düşük değer $21^{\circ} \mathrm{fH}$, en yüksek değer $53^{\circ} \mathrm{fH}$, ortalama $35^{\circ} \mathrm{fH}$ ve standart sapma değerinin 7.54 olarak tespit edilmiştir (Şekil 8).

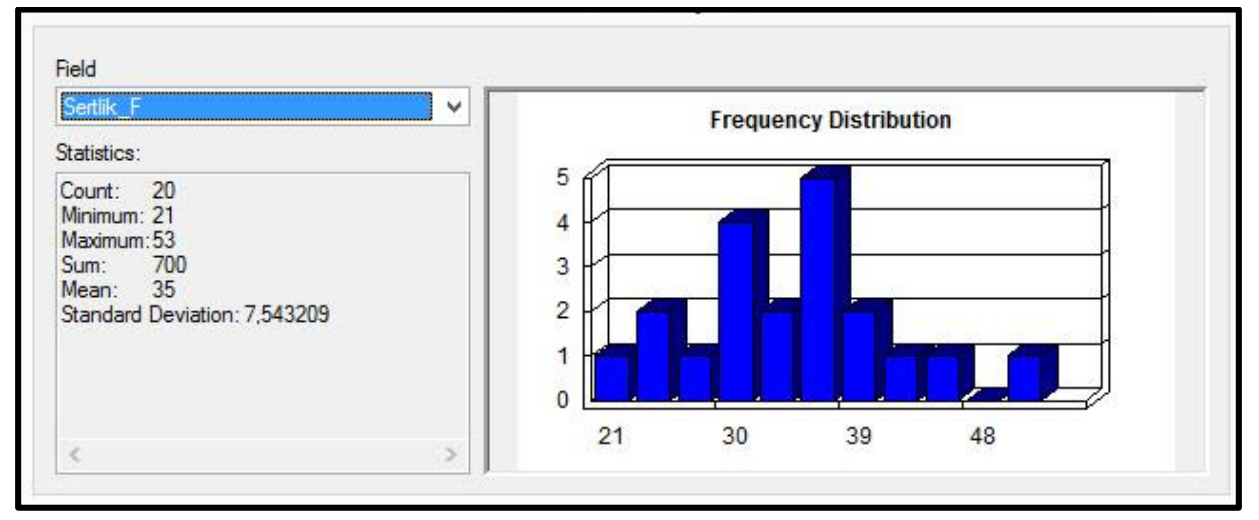

Şekil 8. Fransız sertliği (OfH) için frekans dă̆ıllım

Dünya Sağlık Teşkilatı (WHO) tarafından hazırlanan suların sertlik derecesine göre sınıflandırılmasına göre sınıflandırılmıştır. Buna göre Fransız sertliğine göre 3 örnek orta sert, 17 örnek sert sular sınıfında yer almaktadır. CaCO3 sertliğine göre $300 \mathrm{mg} / \mathrm{L}$ altında bulunan 3 örnek sert sular sınıfında, geriye kalan 17 örnek ise çok sert sular sınıfındadır.

\section{Sonuç}

Bölgesel jeolojiye bakıldığında, Isparta Büklümü olarak isimlendirilen tektonik bir bölgenin içerisinde yer alan çalışma alanında otokton ve allokton konumlu birimlerin yer almasından dolayı bölgenin stratigrafisini kompleks yapıdadır. Toros karst kuşağı olarak adlandırılan karstik bölgenin batı kısmında yer alan Bucak Havzasında yapılacak yeraltısuyu kalitesi ve hidrojeoloji çalışmalarında karstik akiferlerin varlığı kaçınılmaz bir gerçek olarak karşımıza çıkmaktadır.

Arazi çalışmaları sonucunda ölçülen Fransız su sertlik değerleri 21-46 ${ }^{\circ} \mathrm{fH}$ ve $\mathrm{CaCO}_{3}$ sertliği ise 212-461 mg/L değerleri arasında değişmektedir. Arazi çalışmaları sırasında yerinde yapılan ölçümler sonucunda tespit edilmiş olan Fransız ve $\mathrm{CaCO}_{3}$ su sertlik değerleri CBS ortamında işlenerek su sertlik dağılım haritaları hazırlanmıştır. Su sertlik dağılım haritasının incelenmesi sonucunda alüvyon akifer içerisindeki su sertlik değerlerinin düşük olduğu görülmektedir. Alüvyon akiferdeki yeraltı suyunun sertlik değerinin düşük çıkmasının temel sebebi, alüvyon akiferin çalışma alanın doğusunda yüzeylenen geçirimsiz Ağlasun Formasyonu ve ofiyolitik seri üzerindeki drenaj ağlarından yüzeysel akış ile beslenmesidir. Dolayısıyla su kayaç etkileşimi çok az olup suya sertlik kazandırabilecek $\mathrm{Ca}^{++}$ve $\mathrm{Mg}^{++}$ miktarı mevcut değildir.

Çalışma alanının doğusundaki yeraltısuyu sertlik değerleri yüksek çıkmaktadır. Özellikle Davraz Kireçtaşı'nın oluşturduğu karstik akiferin boşalım noktalarına yakın bölgelerde yüksek su sertlik değerlerinin bulunduğu tespit edilmiştir. Karstik litolojilerin tüm karakteristik özelliklerini taşıyan Davraz Kireçtaşı, gerek yüzey suyu (Onaç Deresi) ve gerekse yeraltısularıyla karşılıklı etkileşimin en iyi geliştiği birimdir. Havzadaki yeraltısularındaki sertliğin en önemli sebebi Davraz Kireçtaşı'nda gelişen kayaç-su etkileşimi olduğu sonucuna varılmıştır.

\section{Teșekkür}

Bu çalışma, Burdur Mehmet Akif Ersoy Üniversitesi, Bilimsel Araştırma Projeleri Koordinatörlüğü tarafından 0112-NAP-10 nolu Normal Araştırma Projesi ile desteklenmiştir. 


\section{Kaynakça}

Adnan, S., \& Iqbal, J. (2014). Spatial analysis of the groundwater quality in the Peshawar district, Pakistan. Procedia Engineering, 1422.

Anderson, T. W., Neri, L. C., Schreiber, G. B., Talbot, F. D., \& Letter, Z. A. (1975). Ischemic heart disease, water hardness and myocardial magnesium. Canadian Medical Association Journal, 113, 199-203.

Blumenthal, M. M. (1951). Batı Toroslarda Alanya ard ülkesinde jeolojik araşatırmalar. Ankara: Maden Tetkik Arama Enstitüsü Yayın No:5.

Bozcu, M. (1996). Kasımlar (Sütçüler-Isparta) yöresinde yeralan Mesozoyik yaşlı denizel tortulların jeolojisi, petrografisi ve organik jeokimyasal yöntemlerle incelenmesi. Isparta: Süleyman Demirel Ünvierisitesi, Fen Bilimleri Enstitüsü Doktora Tezi (yayımlanmamış).

Brunn, J. H., Argyriadis, I., Marcoux, J., Monod, O., Poisson, A., \& Ricou, L. (1971). Antalya'nın ofiyolit naplarının orijini lehinde ve alehindeki kanıtlar. Cumhuriyetin 50. Yılı Yerbilimleri Kongresi (s. 58-70). Ankara: MTA Genel Müdürlüğü Özel Baım.

Çemek, B., Güler, M., \& Arslan, H. (2005). Bafra Ovası Sağ Sahil Sulama Alanındaki Tuzluluk Dağılımının Coğrafi Bilgi Sistemleri (CBS)Kullanılarak Belirlenmesi,. Atatürk Üniversitesi. Ziraat Fakültesi Dergisi, 37(1), 63-72.

Dinç, O. (2000). Coğrafi Bilgi Sistemleri (CBS) Teknolojisi ve Veri Analiz Yöntemleri. Adana: Çukurova Ünviersitesi, Fen Bilimleri Enstitüsü Yayın No:FBE-2000-1.

EPA. (2018). 2018 Edition of the drinking water standards and health advisories tables. Washington, DC: United States Environmental Protection Agency.

Ersoy, Ş. (1990). Batı Toros (Likya) naplarının yapısal öğelerinin ve evriminin analizi. TMMOB JMO Jeo. Müh. Dergisi, 5-16.

ES. (2019, 11 25). Hardness in Drinking Water. New Hampsire Department of Environmental Sevice: https://www.des.nh.gov/organization/commissioner/pip/factsheets/dwgb/documents/dwgb-3-6.pdf adresinden alınd1

George, G. K., Akhilasree, D. G., Chandran, M. L., Reshma, P. R., \& Siga, G. (2015). Study of ground water pollution around an industry using GIS. International Journal of Civil and Structural Engineering Research, 2(2), 145-150.

Gölhan, M., \& Aksoğan, S. (1968). Sert suların yumuşatılması ve Ankara şehri içme ve kullanma kuyunun yumuşatılmasından sağlanacak faydalar. Türkiye İnşaat Mühendisliği IV. Teknik Kongresi, Rapor No:21 (s. 1-24). Ankara: İnşaat Mühendisleri Odası.

Güler, Ç. (1997). Su Kalitesi. Ankara: Çevre Sağllğı Temel Kaynak Dizisi No:43.

Hançer, M. (1996). Isparta güneği, Ağlasun-Bucak civarının jeolojik ve tektonik özellikleri. Isparta: Süleyman Demirel Üniversitesi, Fen Bilimleri Enstitüsü Doktora Tezi (yayımlanmamış).

İleri, B., Gündüz, O., Elçi, A., Şimşek , C., \& Alparslan, M. N. (2007). Tahtalı Havzası Yeraltı Suyu Kalitesinin Coğrafi Bilgi Sistemi Destekli Değerlendirilmesi,. 7. Ulusal Çevre Mühendisliği Kongresi, Yaşam Çevre Teknoloji, (s. 880-888). 24-27 Ekim İzmir.

Jeihouni, M., Toomanian, A., Shahabi, M., \& Alavipanah, S. K. (2014). Groundwater quality assessment for drinking purposes using GIS modelling (case study: city of Tabriz. The International Archives of the Photogrammetry, Remote Sensing and Spatial Information Sciences, XL-2/W3, 163-168. doi:doi:10.5194/isprsarchives-XL-2-W3-163-2014

Karagüzel, R., Taşdelen, S., Özkul, M., \& Bilgin, A. (1995). Investigation of waste water discharge of Bucak (Burdur) and its effects on aquifer. International Earth Sciences Colloquium on the Aegean Region, (s. 693-700). İzmir.

Kavurmacı, M., Altaş, L., Kurmaç, Y., Işık, M., \& Elhatip, H. (2010). Tuz Gölü'nün Aksaray İli yeraltı sularına etkisinin Coğrafi Bilgi Sistemleri kullanılarak değerlendirilmesi. Ekoloji Dergisi, 19(77), 29-34.

Koçyiğit, A. (1981). Isparta Büklümünün (Batı Toroslar) Toros Karbonat Platformunun evrimi. Türkiye Jeoloji Kurumu Bülteni, 24, 1523.

Mane, A. V., Dhanani, K. S., Joshi, K., \& Dhanani, C. S. (2015). Groundwater quality assessment and GIS based mapping of selected areas of Mangrol Coast, Gujarat (India). Journal of Chemical and Pharmaceutical Research, 7(5), 649-660.

Mantzafleri, N., Psilovikos, A., \& Blanta, A. (2009). Water Quality Monitoring and Modelling in Lake Kastoria, Using GIS. Assessment and Management of Pollution Sources. Water Resour. Manage, 3221-3354. doi:DOI 10.1007/s11269-009-9431-4

McNally, N. J., Williams, H. C., Philips, D. R., Smallman-Raynor, M., Lewis, M., Venn, A., \& Britton, J. (1998). Atopic eczema and domestic water hardness. The Lancet, 352, 527-531.

Nas, B., \& Berktay, A. (2001). Coğrafi Bilgi Sistemleri (CBS) kullanılarak Konya kenti yeraltısıyu sertlik haritasının oluşturulması. Coğrafi Bilgi Sistemleri Bilişim Günleri, 13-14 Kasım (s. 135-140). İstanbul: Fatih Üniversitesi.

Oroji, B. (2018). Groundwater vulnerability assessment using GIS-based DRASTIC and GOD in the Asadabad plain. Journal of Materials and Environmental Sciences, 1809-1816. doi:https://doi.org/10.26872/jmes.2018.9.6.201

Öztürk, M., \& Çelik, R. (2008). Diyarbakır Ovasının Yeraltı Su Seviye Haritalarının Coğrafi Bilgi Sistemi (CBS) ile Tesbiti,. 2. Su Politikaları Kongresi, Bildiriler kitabı (s. 125-137). 20-22 Mart Ankara: TMMOB.

Prepas, E. E., Pinel-Alloul, B., Chambers, P. A., Murphy, T. P., Reedyk, S., Sandland, G., \& Serediak, M. (2001). Lime treatment and its effects on the chemistry and biota of hardwater eutrophic lakes. Freshwater Biology, 46(8), 1046-1060. doi:https://doi.org/10.1046/j.1365-2427.2001.00788.x

Sengupta, P. (2012). Challenge of infertility: How protective the yoga therapy is? Ancient Science of Life, 32(1), 61-62. doi:DOI: $10.4103 / 0257-7941.113796$

Sengupta, P. (2013). Potential health impacts of hard water. International Journal of Preventive Medicine, 4(8), 866-875.

Singh, P., \& Khan, I. (2011). Ground water quality assessment of Dhankawadi ward of Pune by using GIS. International Journal of Geomatics and Geosciences, 688-703.

Şengül, F., \& Küçükgül, E. Y. (1995). Çevre mühendiliğinde fiziksel-kimyasal temel işlemler ve süreçlar. İzmir: Dokuz Eylül Üniversitesi, Mühendislik Fakültesi Yayınları, No:153 (3.Baskı).

TSE. (1997). Sular-içme ve kullanma suları, TSE 266. Ankara: Türk Standartları Enstitüsü. 
WHO. (1996). Guidlines for Drinking Water-Second Edition- Volume 2 Health Criteria and Other Supporting information. Geneva: World Health Organization.

Woodcook, N. H., \& Robertson, A. H. (1977). Imbricate thrush belt tectonics and sedimantation as a guide to emplacement of part of the Antalya complex SW Turkey. 6. Colloguium Geology of the Aegean Region (s. 661-671). İsmir: (Seceond Edition, 1985).

Yelekçi, S., Acemioğlu, B., \& Avcı, H. (2012). Kilis il merkezi içme sularının kullanılabilirliğinin araştırılması. Biyoloji Bilimleri Araştırma Dergisi, 5(2), 77-81.

Yılmaz, P. O., Maxwell, J. C., \& Muehlberger, W. R. (1981). Antalya kompleksinin yapısal evrimi ve doğu Akdeniz'deki yeri. Yerbilimleri HÜ. Yerbilimleri Enstitüsü Bülteni , 119-127.

Yomralıoğlu, T. (2000). Coğrafi Bilgi Sistemleri Temel Kavramlar ve Uygulamalar. İstanbul: Seçil Ofset. 